\title{
Community Structure, Succession, and Production of Seaweeds Associated with Mussel-Rafts in the Ria de Arosa, N. W. Spain
}

\author{
Brian E. Lapointe ${ }^{1}$, F. Xavier Niell ${ }^{2}$ and José Miguel Fuentes ${ }^{3}$ \\ ${ }^{1}$ Skidaway Institute of Oceanography, Post Office Box 13687, Savannah, Georgia 31406, USA \\ 2 Instituto de Investigaciones Pesqueras, Muelle de Bouzas, Vigo, Spain \\ ${ }^{3}$ Instituto Espanol de Oceanografia, Laboratorio de La Coruna, La Coruna, Spain
}

\begin{abstract}
Spatial and temporal patterns of community structure, succession, and production of seaweeds associated with mussel-rafts in the Ria de Arosa, Spain, were studied at 4 stations during $1 \mathrm{y}$ (1978-1979). Community structure changed due to seasonal changes in abiotic factors (light, temperature, etc.) and an algal succession on new mussel rafts from an initial ephemeral flora (e.g. Ulva rigida, Enteromorpha spp., Polysiphonia spp.) during fall and winter to a kelp-dominated flora in the summer During summer, Laminaria saccharina dominated the innermost estuarine station, whereas Saccorhiza polyschides dominated the 3 outer stations. Because of the succession to a kelp-dominated community, species diversity and evenness decreased over time, whereas species richness generally increased. The ephemeral community that occurred during fall, winter, and early spring had a relatively low biomass (0.1 to $2.2 \mathrm{~g} \mathrm{C} \mathrm{m}^{-2}$ ) and rate of production ( 0.1 to $1.3 \mathrm{~g} \mathrm{C} \mathrm{m}^{-2} \mathrm{~d}^{-1}$ ) compared to that of the kelp dominated community during late spring and summer $\left(25.0\right.$ to $682.1 \mathrm{~g} \mathrm{C} \mathrm{m}^{-2} ; 0.8$ to $12.0 \mathrm{~g} \mathrm{C} \mathrm{m}^{-2} \mathrm{~d}^{-1}$ ). S. polyschides, an annual kelp species, was the most productive alga; between May and July its production rate averaged $10.2 \mathrm{~g} \mathrm{C} \mathrm{m}^{-2} \mathrm{~d}^{-1}$ at the outermost, highly exposed station. During late spring and summer, seaweed production associated with the mussel-rafts account for ca $8 \%$ of the total phytoplankton production of the Ria de Arosa. The hanging ropes of the mussel rafts provide a habitat for seaweeds within the photic zone and the mussels produce large amounts of $\mathrm{NH}_{4}{ }^{+}$that, along with the $\mathrm{NO}_{3}{ }^{-}$-enriched upwelled waters, supports the high seaweed production. Moreover, the periodic introduction of new ropes onto the rafts continually selects for $S$. polyschides and other opportunists that are highly productive.
\end{abstract}

\section{INTRODUCTION}

The Ria de Arosa is the largest of 5 rias that comprise the Rias Bajas in Galicia, N. W. Spain (Fig. 1). Physically, this ria is a fjord-like embayment with a surface area of $230 \mathrm{~km}^{2}$, an average depth of $19 \mathrm{~m}$, a maximum depth of $70 \mathrm{~m}$, and a mean tidal range of $2.7 \mathrm{~m}$. Temperature and salinity do not vary excessively in the ria; salinity at depth is always greater than $34 \%$, and surface water temperatures annually range from $12^{\circ}$ to $20{ }^{\circ} \mathrm{C}$ (Gallego, 1971, 1975; Otto, 1975).

The Arosa produces a large crop of the edible mussel Mytilus edulis that is supported by high phytoplankton production due mostly to upwelling (Tenore and Gonzalez, 1975). A combination of coastal wind patterns and basin stratigraphy causes intermittent upwelling of $\mathrm{NO}_{3}{ }^{-}$-rich deep oceanic water into the photic zone of the ria that results in high primary production in the middle to inner part of the ria. The primary production supports an intensive raft culture of some $120000 \mathrm{~m}$ tons wet weight of mussels per year (Roman and Perez, 1979). There are over 2000 mussel rafts in the Ria de Arosa. An average raft is $20 \times 20 \mathrm{~m}$ in size and contains ca 700 ropes of $8 \mathrm{~m}$ length. Seed mussels are allowed to settle naturally on the ropes. As the mussels grow, the ropes are periodically (2-3 times a year) 'unfolded', i.e., as the mussels grow, crowding is reduced by thinning out the number of mussels per length of rope; commercial size mussels are harvested and small mussels are used to make new ropes.

The mussel ropes provide habitat, and mussel biodeposits are a source of detritus for biota associated with the ropes (Tenore and Gonzalez, 1975; Roman and Perez, 1979). Seaweeds grow well in the near- 


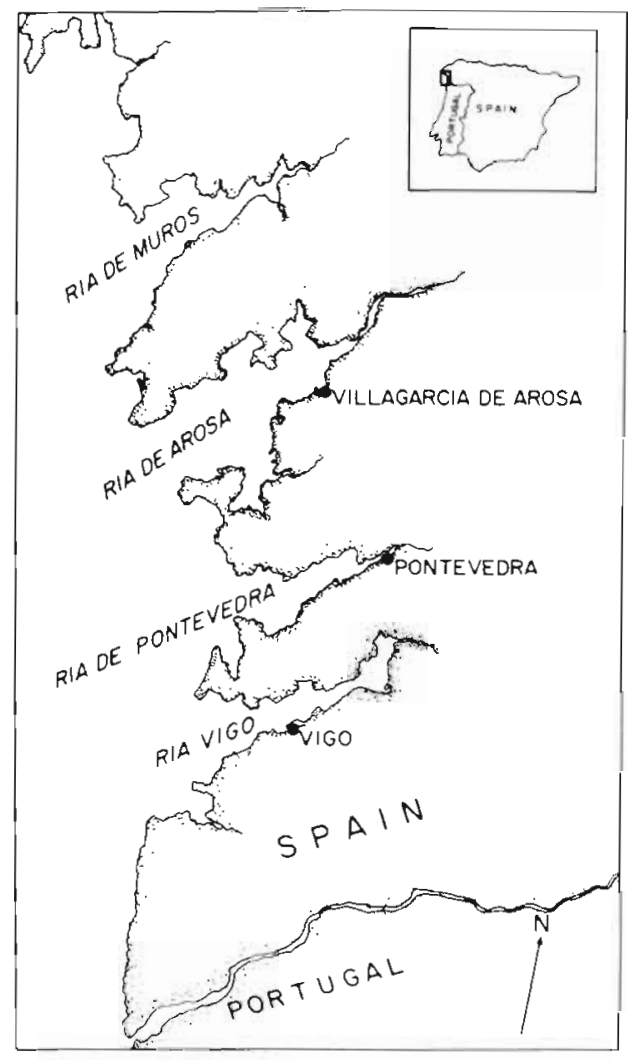

Fig. 1 The Rias Bajas of N.W Spain

surface mussel rope habitat where they are constantly provided with large amounts of dissolved nutrients (e.g. $\mathrm{NH}_{4}{ }^{+}$) excreted by the mussels and epifauna. Because the mussel ropes are 'unfolded', the community structure of associated seaweeds is influenced not only by natural processes, but also by the periodic management by man.

The rocky, exposed coast of Galicia has a particularly rich and productive seaweed flora. Upwelling provides a less fluctuating, colder temperature regime - usually found in more northerly latitudes - and accounts for the unique, discontinuous Galician flora (Fischer-Piette, 1963). Several investigators have described the algal vegetation of this area and almost 500 species have been reported to date (Ardre, 1957; Seoane, 1957; Danze, 1968; Niell, 1978). Studies of community structure, succession, and production have concentrated mostly on the intertidal flora (Niell, 1974. 1977, 1979). Little is known of the sublittoral flora. A study of distribution and productivity of Laminaria ochroleuca and Saccorhiza polyschides in the Ria de Aldan (John, 1971) was short-term (1 month) and did not measure seasonal growth patterns. Such sublittoral species can have high rates of primary production (John, 1971; Mann, 1972) and could contribute significantly to the primary production of the rias.
In this paper we report seasonal changes in the community structure, succession, and production of seaweeds associated with mussel rafts. The term 'succession' is interpreted variously (Foster, 1975). Here we use the term to mean only temporal changes in community composition.

\section{MATERIALS AND METHODS}

Seaweed samples were collected at 4 stations (A, B, C, D) in the Ria de Arosa (Fig. 2) at 2-month intervals from September, 1978, to July, 1979 to study spatial (horizontal and vertical) and temporal distribution patterns. Because the intent of the study was to monitor typical mussel rafts, we chose rafts that were 'unfolded' between September and November and followed the colonization and growth of seaweeds through the following summer. Six ropes were randomly chosen 3 inner and 3 outer ropes) from each of 2 rafts at each station. Divers took seaweed samples from successive 1-m lengths of the ropes down to the lower limit of vegetation (usually $3-4 \mathrm{~m}$ ). Only macroscopic algae, greater than $5 \mathrm{~mm}$ in height, were collected. Bluegreen and small filamentous algae, although present on the mussel ropes, were not considered in this study

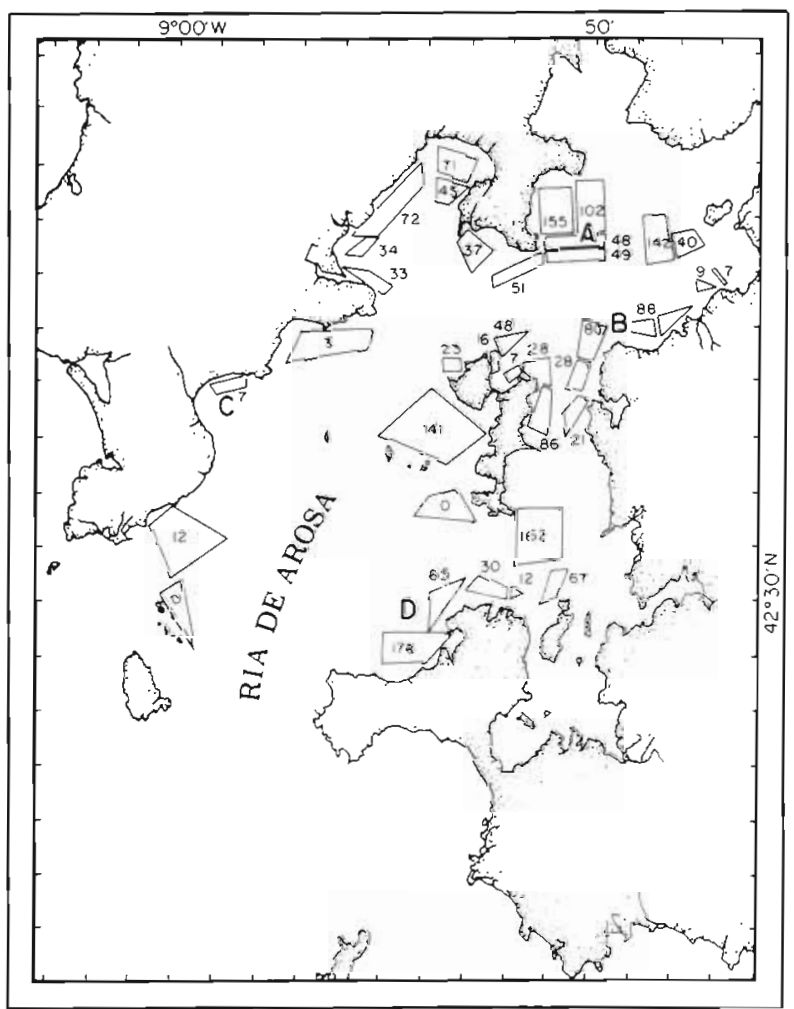

Fig. 2. The Ria de Arosa showing 'polygons' of mussel rafts The number inside the polygons indicates the number of rafts. $A, B, C, D$ are seaweed stations 
because of problems of collecting and quantifying. Depth was measured with graduated $(1 \mathrm{~m})$ nylon droplines and samples were placed in nylon mesh bags. A plot of species number from cumulative samples showed that 6 ropes adequately reflected the species composition of a raft. However, biomass estimates for a raft (6 ropes) had high variance/mean ratios suggesting a contagious distribution.

Abundant species in samples (e.g. kelps) were wetweighed on station with a Hanson hanging balance (Model 842), but most of the samples were returned to the laboratory where the species were sorted, identified, and wet-weighed. Subsamples for biomass conversion factors for each species were dried $190^{\circ} \mathrm{C}$ for $24 \mathrm{~h})$, ashed $\left(475^{\circ} \mathrm{C}\right.$ for $\left.8 \mathrm{~h}\right)$, and carbon-nitrogen content determined on a Perkin-Elmer Model 240 Elemental Analyzer

Spatial and temporal changes in species distribution and community composition was delimited by cluster analysis, using a percent similarity index (Sanders, 1960 ) with the biomass data of the year survey. This index is a measure of the percentage of flora common to pairs of samples. To obtain this, the percentage composition of a species in each sample is calculated, and all possible pairs of samples are compared. The index value is determined for each pair by summing the smaller of two percentages for those species in both samples. For example, if 2 samples (Sample 1 containing $25 \%$ of Species A, $20 \%$ of Species B, and $55 \%$ of Species C; Sample 2 containing $9 \%$ of Species A, $60 \%$ of Species B, and $40 \%$ of Species C) are compared, the index of similarity would be $60 \%$, the sum of 0,20 , and $40 \%$. We used a dendrogram to display the results of the cluster analysis. This analysis was also used to investigate differences in species distribution due to depth from data in the July campaign. Biomass values were also used to calculate diversity by the Shannon index ( $\mathrm{H}^{\prime}$; Wilhm, 1968), evenness (Pielou, 1966) and species richness (Margalef, 1969).

Biomass values for the major species were converted to $\mathrm{g} \mathrm{C} \mathrm{m}^{-2}$ of raft surface for each sampling period; differences between these values over time were used to estimate production rates. Because ephemeral species such as Ulva rigida, Enteromorpha spp., and Polysiphonia spp. can have several generations a year (Prescott, 1968), we used an experimentally-derived turnover rate (1 turnover month ${ }^{-1}$; Niell, unpubl.) to give a better estimate of true net production for these species. Several young plants of each kelp species present on the ropes (Saccorhiza polyschides, Laminaria ochroleuca, Laminaria saccharina) were tagged to measure their growth and development. Blade elongation agreed reasonably well with biomass increase; that is, there was not a great loss of tissue from the distal end of the blade during growth as observed for other benthic kelps (Mann, 1972). The reduced wave action in the mussel-raft habitat compared to that of a benthic, sublittoral kelp community may account for this disparity. Thus, we used biomass change over time to estimate net production for the kelps.

To determine variations in the relationship of blade length to stipe length in Saccorhiza polyschides due to growth in dense stands, we measured a large number of plants $(\sim 160)$ from outside ropes at Station $D$ in July. The ratio describing this relationship is:

$$
\mathrm{P} / \mathrm{S}=\frac{\text { total plant length }}{\text { stipe length }}
$$

for $S$. polyschides occurring within $1-\mathrm{m}$ intervals down to its lower depth limit on 3 ropes.

\section{RESULTS}

Thirty-one species of seaweeds were collected in the ria during the year survey (Table 1), including 9 Chlorophyta, 15 Rhodophyta, and 7 Phaeophyta. Most of these species are opportunistic and as a whole, present a small percentage (ca $6 \%$ ) of the flora reported for this area.

Changes in both biomass and species composition showed a definite seasonal trend. Ephemeral species such as Ulva rigida, Enteromorpha spp., and Polysiphonia spp. dominated the raft flora from November to January, but their biomass was relatively low, ranging from 0.1 to $2.2 \mathrm{~g} \mathrm{C} \mathrm{m}^{-2}$. In January, small sporelings of Saccorhiza polyschides and Laminaria spp. appeared at all stations, especially at Station D, where S. polyschides was already at juvenile size $(\sim 100 \mathrm{~g}$ each). These kelps grew throughout the spring to dominate the raft flora during the summer. In July, the biomass of the dominants $S$. polyschides and $L$. saccharina ranged from 25.0 to $682.1 \mathrm{~g} \mathrm{C} \mathrm{m}^{-2}$ at all stations, whereas ephemeral species ranged only from 0.2 to $8.4 \mathrm{~g} \mathrm{C} \mathrm{m}^{-2}$.

Samples clustered seasonally due to these changes in dominance (Fig. 3). The specific similarity index used is greatly influenced by changes in density of dominants. For example, clustering of samples from November to March was caused by early dominance of species of Rhodophyta and/or Chlorophyta, while that of May to September was caused by kelps (Saccorhiza polyschides or Laminaria saccharina). A cluster caused by co-occurrence of similar amounts of several species of seaweeds from 2 seaweed divisions was evident for March and May samples. This cluster represents an intermediate stage of succession, just prior to Saccorhiza becoming dominant. The dominance of $S$. polyschides is easily seen in its cluster where there is 


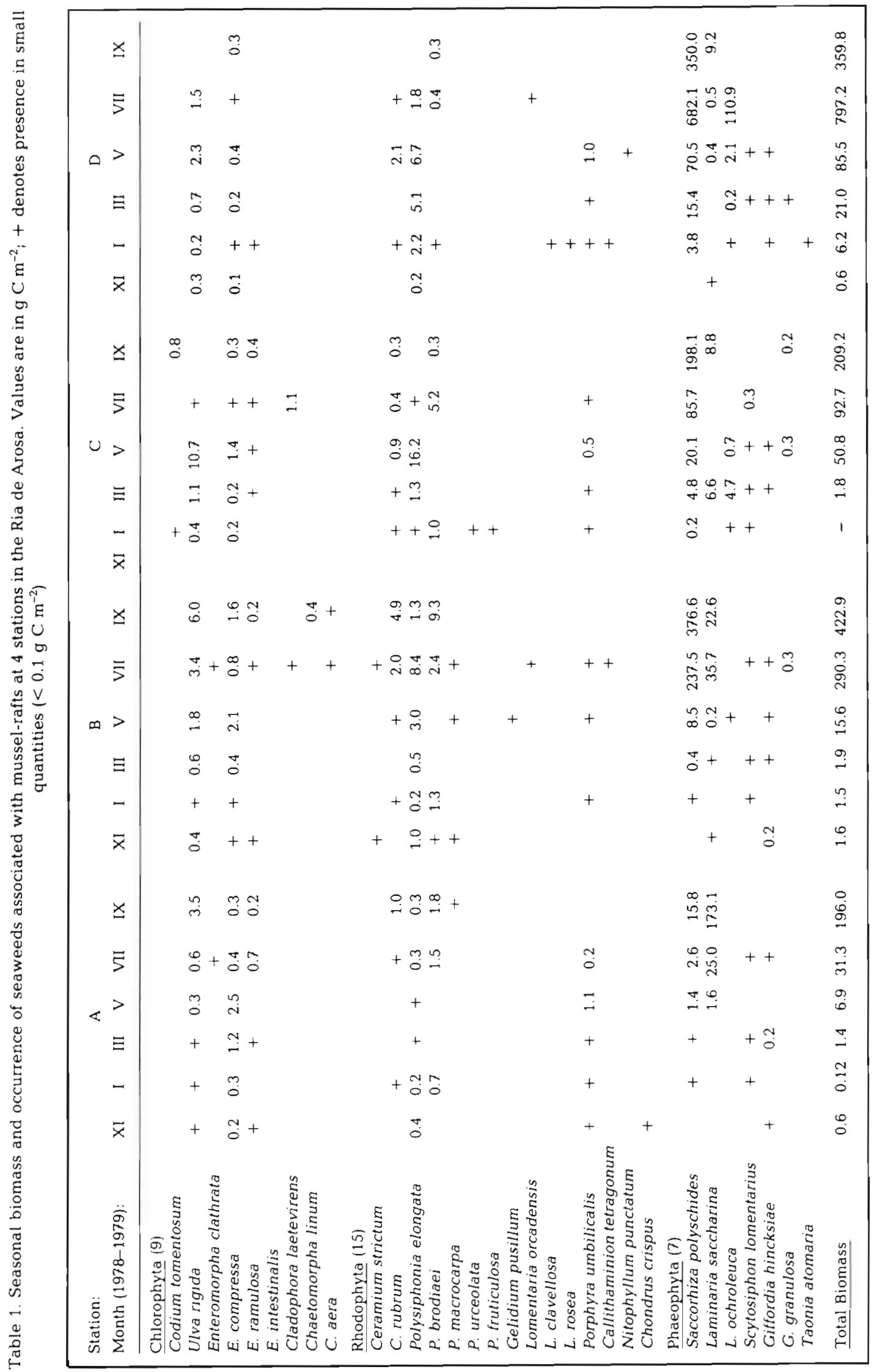




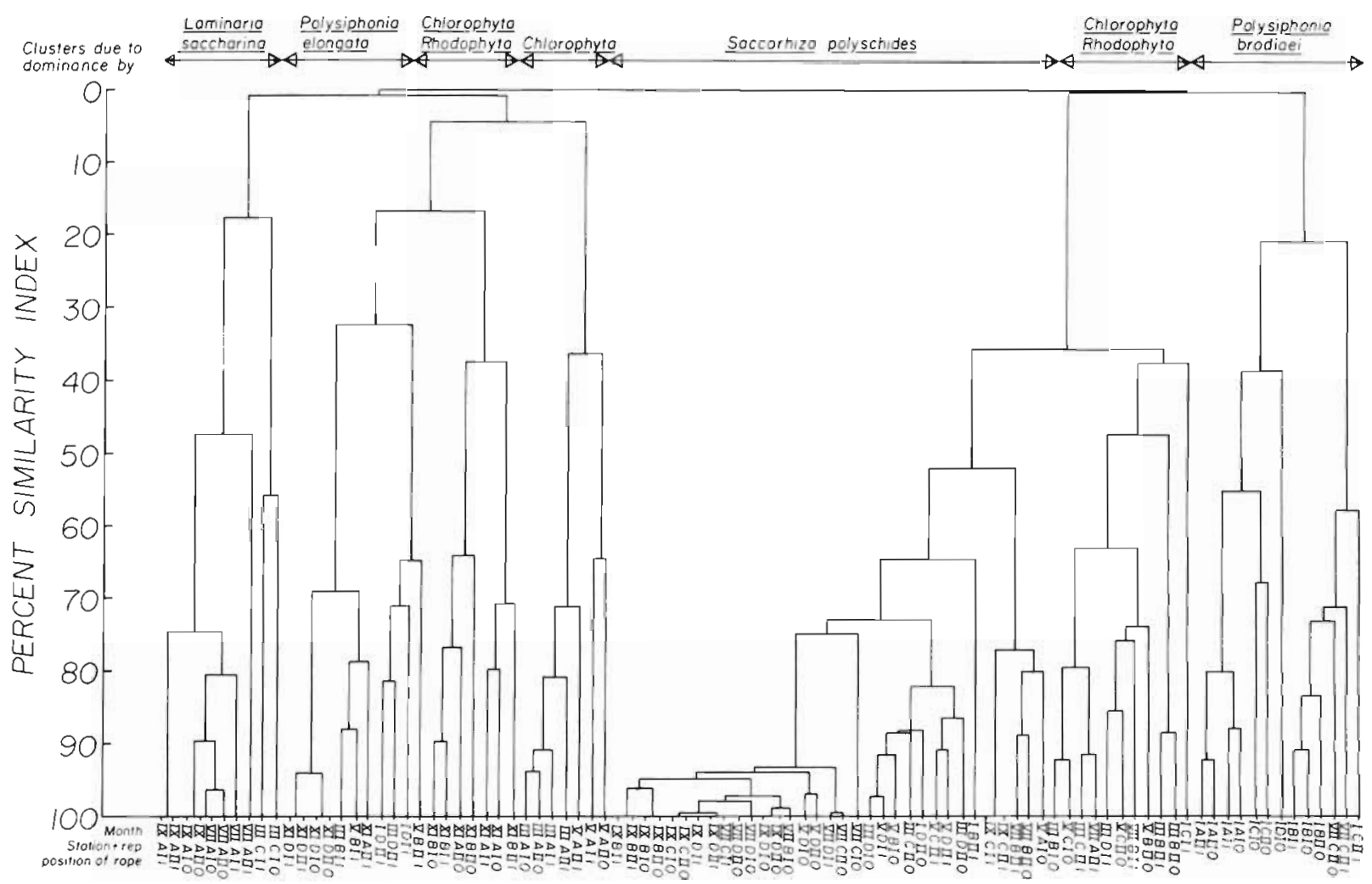

Fig. 3. Dendrogram illustrating both spatial (station-station) and temporal (seasonal) clustering of seaweed samples from musselropes (inside and outside of raft) at 4 stations (A, B, C, D) at 2-month intervals (I, III, V, etc.) during 1978-1979 in the Ria de Arosa, N.W. Spain

increasing similarity with time (i.e. May to September) due to increasing dominance by $S$. polyschides.

Within the seasonal delimitations, areas of the ria showed a high degree of similarity. Only samples from Station A, the innermost station, were delimited from other areas of the ria. For example, March and May samples clustered due to dominance by Ulva rigida and Enteromorpha spp., and July and September samples clustered due to dominance by Laminaria saccharina (Fig. 3).

July samples from all 4 stations showed no delimitation due to depth on the ropes (Fig. 4). A cluster of samples dominated by Saccorhiza polyschides was evident for Station D samples. S. polyschides occurred to $11 \mathrm{~m}$ at this station, deeper than any other station. The dominance of this kelp at depth was reflected in the extremely high similarity among these samples (Fig. 4). Also, most samples in this cluster were from outer ropes, indicating that growth of $S$. polyschides was strongly affected by the location of the ropes (inner vs. outer ropes).

Species diversity and evenness changed due to seasonal succession, decreasing from November to September at all four stations, with the lowest values occurring at Station D in September (Fig. 5a, b). Species richness increased with time through July at
Stations A and B but showed no major changes throughout the year at Stations C and D (Fig. 5c).

There were distinct seasonal trends in the $\mathrm{C}: \mathrm{N}$ ratio of seaweeds on the mussel-rafts. The C:N ratio of Saccorhiza polyschides, Laminaria saccharina, and Ulva rigida increased from winter to summer; how ever, the time course for these changes was quite different (Fig. 6). For example, the C:N ratio of $L$. saccharina increased in March from a minimum of 11.0 to a maximum of 15.2 in July. However, S. polyschides maintained a relatively low $\mathrm{C}: \mathrm{N}$ ratio of $<11.2$ through July increasing in September to a maximum of 15.8. The C:N ratio of $U$. rigida increased linearly from a minimum of 7.5 in March to 11.5 in September. The C:N ratio of Polysiphonia elongata did not change much seasonally, varying between 6.5 and 7.5 . In addition, there were consistent differences in $C: N$ ratios throughout the year between species representing the three seaweed divisions; $P$. elongata had the lowest values; $U$. rigida, intermediate values; and $L$. saccharina and $S$. polyschides, the highest values.

Changes in seaweed production throughout the year were due to seasonal changes in light and temperature, as well as to temporal changes in species composition. From November until May total production at all stations was low, ranging from 0.1 to $1.3 \mathrm{~g} \mathrm{C} \mathrm{m}^{-2}$ 


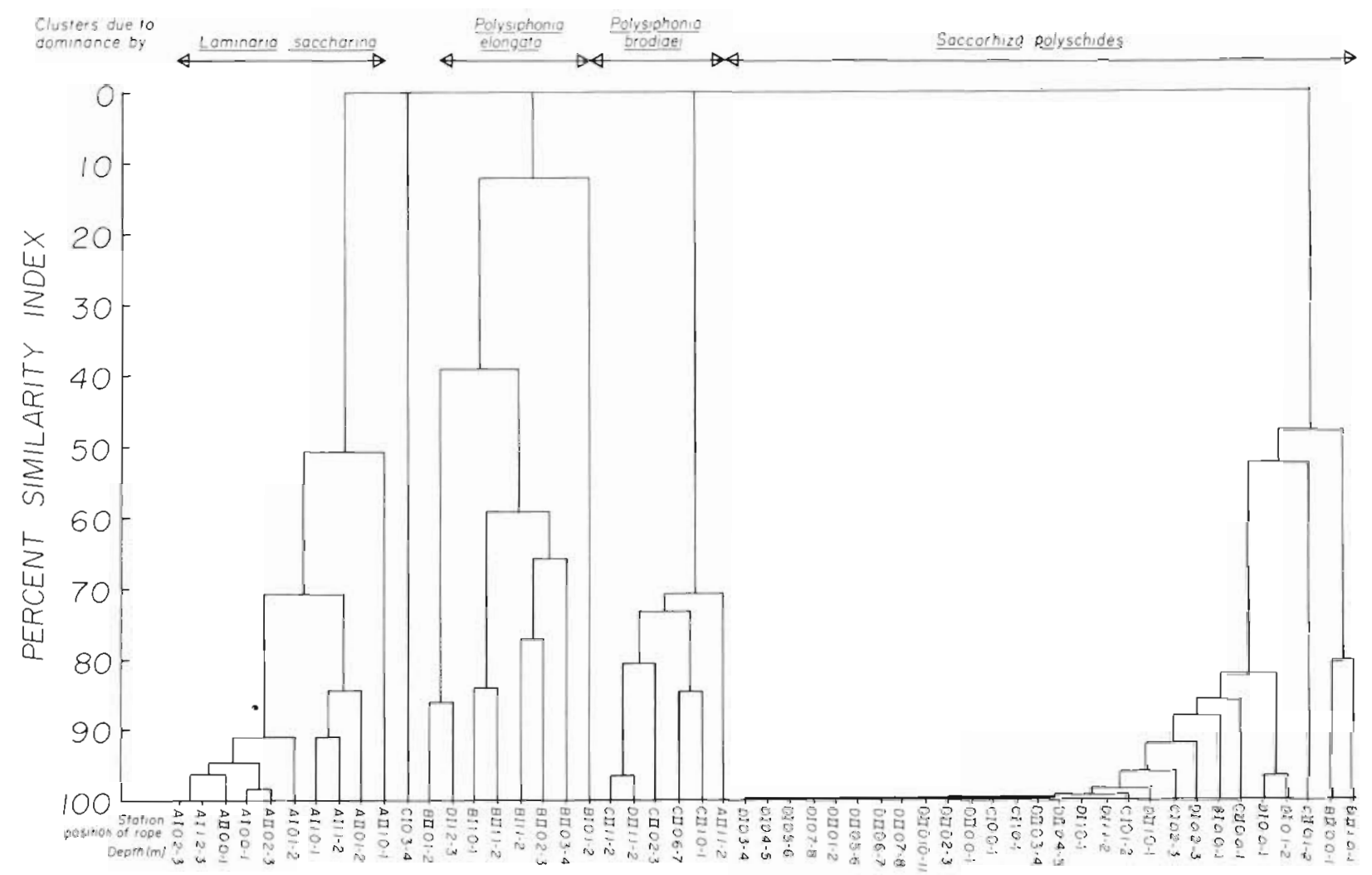

Fig. 4. Dendrogram of seaweed samples from different depths $(0-1 \mathrm{~m}$, etc) on mussel-ropes at 4 stations (A, B, C, D) in the Ria de Arosa during July, 1979

$\mathrm{d}^{-1}$ (Fig. 7). During this time, ephemeral species (Ulva rigida, Enteromorpha spp., Polysiphonia elongata, etc.) contributed a relatively large share of the total seaweed production. From May until September, however, total production was much higher, ranging from 0.8 to $12.0 \mathrm{~g} \mathrm{C} \mathrm{m}^{-2} \mathrm{~d}^{-1}$, and was dominated by kelps. Saccorhiza polyschides was the most productive species at Stations $B, C$, and $D$, with an average production rate of $10.2 \mathrm{~g} \mathrm{C} \mathrm{m}^{-2} \mathrm{~d}^{-1}$ from May until July at Station $D$, the most productive station. Laminaria saccharina dominated the production at Station $A$, the inner-most station with a maximum production rate of $2.6 \mathrm{~g} \mathrm{C} \mathrm{m}^{-2} \mathrm{~d}^{-1}$ between July and September.

The $P / S$ ratio (total plant length/stipe length) for Saccorhiza polyschides growing in dense strands on outer ropes at Station. D in July decreased significantly with depth (Fig. 8). Thus, plants growing at depth had relatively longer stipes than those at shallow depths.

\section{DISCUSSION}

\section{Community Structure and Succession}

In succession from a highly diverse-low productivity stage to a less diverse-high productivity stage, kelps decrease diversity of the raft flora by lowering the evenness component of species diversity. Such a decrease in diversity through succession has been described by Margalef (1963). A similar decrease in diversity occurs in Macrocystis forests during late succession but this was attributed to inhibition of ephemeral species due to shading by perennial species (Foster, 1975). A drop in species richness occurred at one of our stations (D) due to intense growths of Saccorhiza polyschides; but, in general, our observed decreases in diversity during succession on mussel-ropes was primarily due to decreased evenness rather than decreased species richness.

However, contrary to the popular view (Odum, 1969), community productivity increased during the later stages of succession. This disparity is largely due to organism size. The early ephemeral community is composed mostly of small plants that only occupy a space close to the mussel ropes. The larger kelps occupy space further away from their attachment on the ropes and this increased community production (an areal measurement) during the late succession. The production/biomass (P/B) ratio helps to correct for this change in organism size. For example, the $\mathrm{P} / \mathrm{B}$ ratio at Station D, if calculated from our data, decreased from 0.03 in January to 0.01 in July. These data support the 

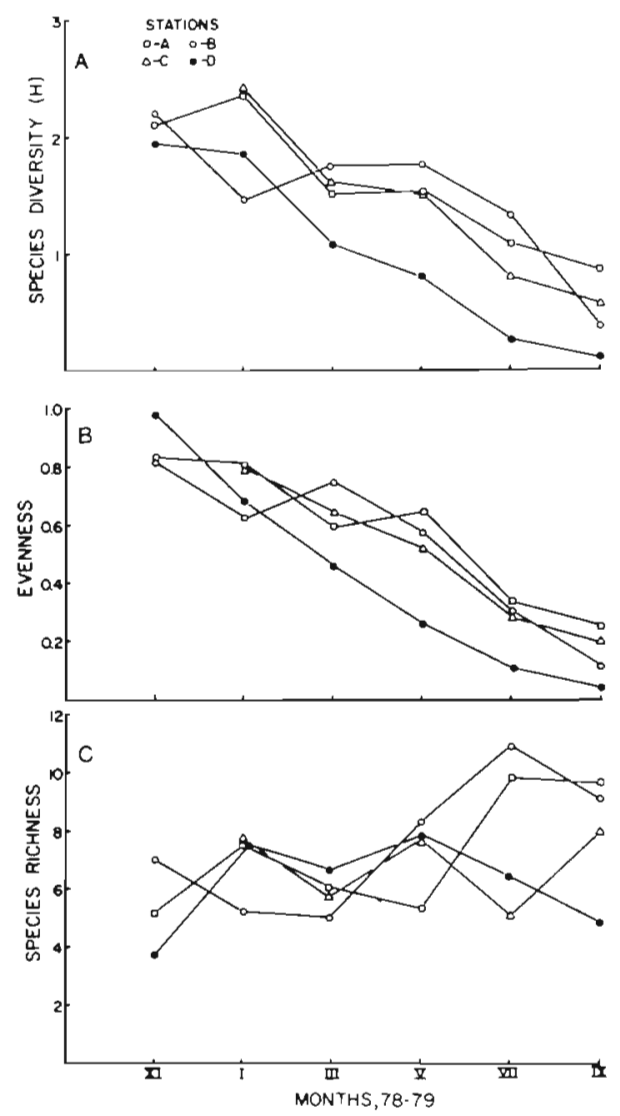

Fig. 5. Species diversity (A), evenness (B), and species richness (C) of the mussel-raft seaweed community at 4 stations (A, B, C, D) during 1978-1979 in the Ria de Arosa

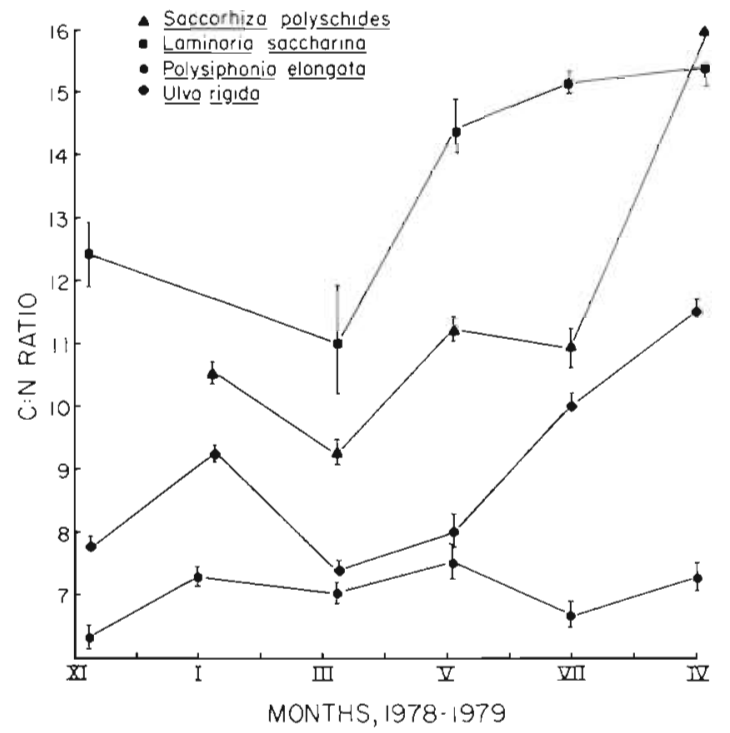

Fig. 6. Seasonal variation of $\mathrm{C}: \mathrm{N}$ ratio of 4 seaweed species associated with mussel-rafts in the Ria de Arosa
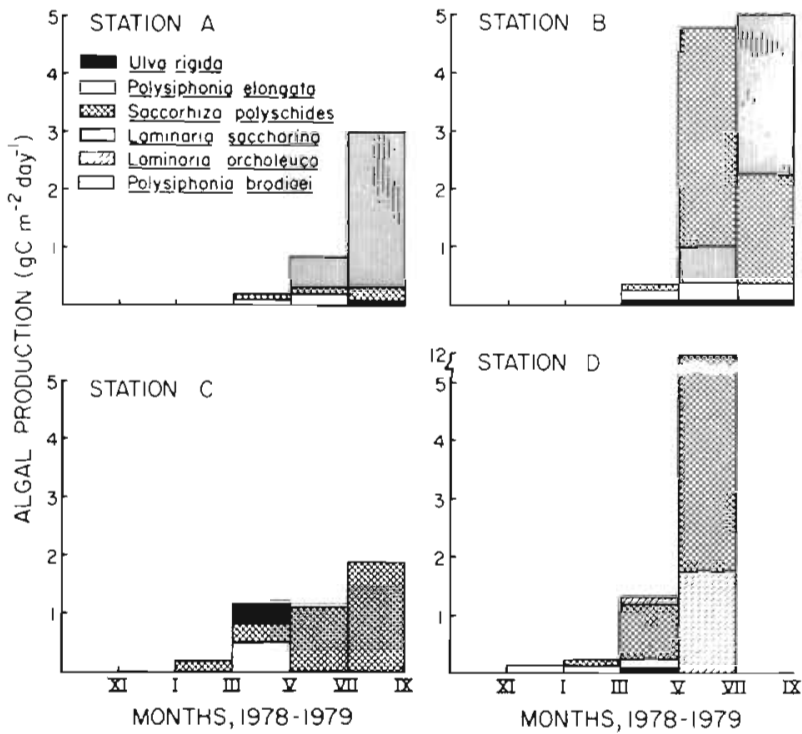

Fig. 7 Seasonal production rates of the major seaweed species associated with mussel-rafts at 4 stations (A, B, C, D) in the Ria de Arosa

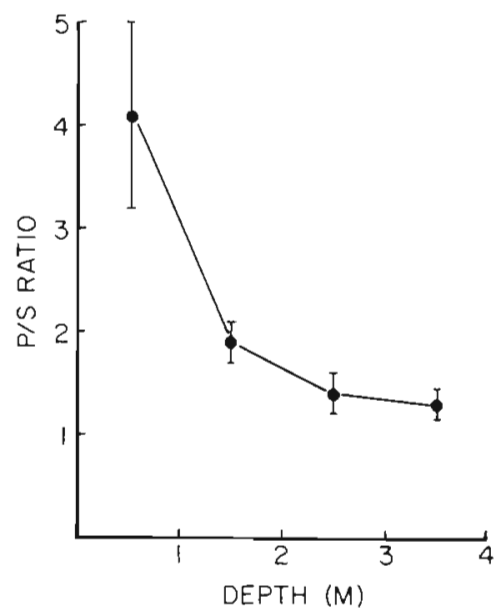

Fig. 8. Saccorhiza polyschides. P:S ratio (total plant length/ stipe length) for plants growing at various depths in dense stands during July 1979, in the Ria de Arosa

classical view where succession from an immature to a mature community is associated with a decrease in the $\mathrm{P} / \mathrm{B}$ ratio (Odum, 1969). Similar changes in community structure, production and $\mathrm{P} / \mathrm{B}$ ratios occurred during succession of cleared surfaces in intertidal algal communities in the Ria de Vigo, Spain (Niell, 1979).

Temporal changes in community structure are caused not only by seasonal factors that regulate growth rates of seaweeds (light, temperature, etc.), but also by the season-dependent regulation of algal reproduction and its relation to the time of "unfolding" ropes. For example, Niell (1979) found that species that colonized cleared areas in the intertidal zone of the Ria de Vigo varied seasonally. In regard to the sublittoral mussel-rope community, this is not as important for 
ephemeral species that have many generations a year as it is for kelps like $S$. polyschides that have only seasonal recruitment, mostly in the late fall and winter (Norton and Burrows, 1969). New mussel ropes prepared in the late spring or summer would not only lack abundant spores of Saccorhiza polyschides, but the few sporophytes that might settle and develop would not fully exploit the late spring and summer rapid growth period. We observed that mussel ropes unfolded in the spring were colonized mostly by ephemerals throughout the summer months, although a few small sporophytes of $S$. polyschides, Laminaria ochroleuca, or $L$. saccharina were present. Thus, the time of unfolding is an important factor that affects community structure and succession of seaweeds on the rafts.

That the mussel rafts are unfolded at least once a year is also important in determining the fate of algal succession, especially at stations dominated by Saccorhiza polyschides. $S$. polyschides is an annual species (Phillips, 1896) whereas Laminaria ochroleuca and $L$. saccharina are perennials (Newton, 1931). Newly created space in a forest of another perennial kelp, L. hyperborea, also became dominated by dense stands of $S$. polyschides during the first year (Norton and Burrows, 1969). After the sporophytes of S. polyschides fruited and decayed in fall, Norton and Burrows found that young sporophytes of $L$. hyperborea (whose development has been retarded due to shading) began to grow and could then occupy the area for up to $15 \mathrm{y}$. Thus, once forests of $L$. hyperborea are developed (by 2 y time), they prevent the growth of $S$. polyschides by shading. L. hyperborea forests can be regarded as a 'climax' or stable community due to the long life of this species. This succession fits the inhibition model of Connell and Slatyer (1977) in which later species cannot grow to maturity in the presence of earlier ones; they appear later because they live longer and, so, gradually accumulate as they replace earlier ones. Although long-lived perennial kelp species ( $L$. ochroleuca, L. saccharina) occurred at all our stations, the continual 'unfolding' of the mussel-ropes selects for dominance of $S$. polyschides by continually creating new space. In effect, this management prevents the otherwise natural succession on the mussel ropes to a stable community composed of perennial kelps. A similar model of algal succession has been described for seaweeds recolonizing cleared boulders in the intertidal zone of southern California, USA (Sousa, 1979).

Station A differed from other stations because of salinity and temperature fluctuations. Fresh water from the Rio Ulla moves along the northern coast of the ria in the region of Station A (Donze, 1968); consequently, this area has wider salinity and temperature fluctuations than other areas of the ria (Otto, 1975). Such fluctuations are a major factor affecting distributions of seaweeds (Fralick and Mathieson, 1975). Donze (1968), using a similarity coefficient to study the benthic littoral and shallow sublittoral vegetation in the Ria de Arosa, found that vegetation in this area was different from the other parts of the ria due to estuarine effects. The Ulvaceae that we found to dominate mussel rafts at Station A during spring are the most euryhaline and eurythermal of all algae other than blue-greens (Guist and Humm, 1976). Also, Laminaria saccharina, the dominant kelp at this station during summer, tolerates wide fluctuations in salinity and temperature so that wave exposure often controls its distribution (Druehl, 1967). But, because both exposure and salinity are lower at Station A than at the other stations (Donze, 1968), the relative importance of these two factors in regulating the distribution of the two dominant kelps, Saccorhiza polyschides and $L$. saccharina is unknown. In general, then, the major spatial changes in seaweed communities associated with mussel-rafts is between the more sheltered, estuarine area (Station A) and outer, more exposed marine areas (Stations B, C, and D) of the ria.

The overall lack of different floral assemblages with depth on the mussel-ropes supports the continuum theory of algal vegetation. Some studies have suggested zonation of sublittoral algae with depth (e.g. Prentice and Kain, 1976), but others (see Chapman, 1979) believe that the littoral fringe/eulittoral discontinuity is the only distinct vertical break in floral assemblages. Although the dominance of Saccorhiza polyschides at depth at Station D during July (Fig. 4) suggests a distinct 'Saccorhiza zone', in actuality, this plant was found continuously along the mussel ropes, from 0 to $11 \mathrm{~m}$. Thus, we found no sharp discontinuity with depth, even in this case. In addition, the distinct spatial and temporal groupings that occurred in our cluster analyses resulted partially because the similarity index we used is strongly affected by dominant species. Thus, use of this index tends to favor the zonation theory. Another index not as strongly affected by dominants would better detect subtle differences in rare or nonabundant species between dominant vegetation types and even further support the continuum concept. Clearly, the mussel rope habitat is not really a 'natural' system but still our results support the contention of Boudouresque and Lück (1972) that marine vegetation consists of a continuum of species assemblages.

\section{Seasonal Changes in C:N Ratios}

Seasonal changes in the $C: N$ ratios seaweeds on the mussel-ropes may reflect their growth physiologies. The ria is not as nitrogen-limited as other 
coastal waters, so that seasonal changes in $\mathrm{C}: \mathrm{N}$ ratios are probably more affected by light (i.e. physiological control) rather than by dissolved nitrogen (i.e. control by aqueous environment). For example, light, by controlling growth rate and pigment content, can alter the $\mathrm{C}: \mathrm{N}$ ratio and nitrogenous nutrition of a macroalga even though $\mathrm{NO}_{3}{ }^{-}$is available at growth saturating levels (Lapointe, 1981; Lapointe and Tenore, 1981). Thus, the increase in C:N ratio of Ulva rigida and the lack of change in $\mathrm{C}: \mathrm{N}$ ratio of Polysiphonia elongata may be related to the different effects of light on growth of these algae. Growth of $U$. rigida saturates at high light levels (Ramus, 1978); consequently, it is a fast-growing plant with a high photosynthetic efficiency (Lapointe and Tenore, 1981); P. elongata, however, saturates at relatively low light levels, and is a relatively slow-growing alga (Fralick and Mathieson, 1975; King and Schramm, 1976; Sousa, 1979). Thus, nitrogen may become more growth-limiting to $U$. rigida than $P$. elongata and cause the observed increase in $\mathrm{C}: \mathrm{N}$ of $U$. rigida during high light periods (i.e. in summer). Although these 2 algae co-exist and compete for space on the mussel-ropes, the relative competitive advantages of their different growth physiologies are obscured by their different reproductive abilities.

Competitive advantages of $\mathrm{C}: \mathrm{N}$ ratios and growth physiologies may be more evident for 2 co-existing kelps, Laminaria saccharina and Saccorhiza polyschides. Perennial kelps such as L. saccharina and $L$. hyperborea store carbon compounds in summer to provide materials and energy for a winter-early spring growth maxima (Lüning et al., 1973). This strategy probably caused the increases observed by us in $C: N$ during late spring-early summer for $L$. saccharina. However, the annual kelp $S$. polyschides maintained a low $C: N$ through the summer until September when it increased with the onset of sporulation and tissue decay. The low $\mathrm{C}: \mathrm{N}$ in $\mathrm{S}$, polyschides might be maintained by efficient nutrient transport systems that would confer a competitive growth advantage during high light-rapid growth periods. Such a strategy would be of great importance to an annual opportunist like $S$. polyschides (an r-strategist) to take advantage of summer light and temperatures compared to the slower growing perennial, L. saccharina (a k-strategist).

\section{Production}

Although phytoplankton production is greatest in the middle of the ria where $\mathrm{NO}_{3}{ }^{-}$-rich water upwells into the photic zone (Otto, 1975; Tenore and Gonzalez, 1975) seaweed production was greatest at Station D in the outer ria due to several factors. First, newly unfolded ropes at Station D are near large benthic sublittoral populations of Saccorhiza polyschides (Donze, 1968). Because colonization of new substratum is a function of its distance from populations of potential colonizers (Foster, 1975), this would enhance good spore settlement on mussel-rafts in this area. Second, Station $D$ is the outermost and deepest station and has the greatest water movement due to ocean swells. Water turbulence increases growth of $S$. polyschides (Norton, 1969), probably by reducing boundary layers. Third, the water at Station $D$ is clearer than the inner ria water (Cabanas, personal communication) and, therefore, superior for phytosynthesis. Higher levels of particulate organic matter at the inner ria stations reduce and selectively absorb light, both of which reduce energy available for photosynthesis (Jerlov, 1968). Consequently, S. polyschides grows deeper at Station $D(11 \mathrm{~m})$, especially on outer ropes receiving more light, than at the other stations (ca $4 \mathrm{~m}$ ).

Table 2 compares production rates of several intertidal species found in the Rias Bajas and intensive mass outdoor seaweed cultures with that found for Saccorhiza polyschides at Station D. To facilitate comparison, measurements were from a 2-month period during May and June. Because this period represents maximum seasonal light, these values can be considered as estimates of maximum short-term yields for each species. As shown in Table 2, production by S. polyschides on the mussel-rafts is comparable to that of well developed stands of Himanthalia elongata, one of the most productive algae of the intertidal zone of the Rias Bajas (Niell, 1977). However, because of differences in growth measurements, one must be cautious in comparing production rates. For example, Niell

Table 2. Net seaweed production in various natural and managed systems during early summer (May-July) as measured by biomass change over time

\begin{tabular}{|c|c|c|}
\hline Species and location & Reference & $\begin{array}{l}\text { Production } \\
\left(\mathrm{gC}^{-2}\right. \\
\left.\mathrm{d}^{-1}\right)\end{array}$ \\
\hline $\begin{array}{l}\text { Pelvetia canaliculata } \\
\text { Ria de Vigo, N.W. Spain }\end{array}$ & Niell (1977) & 4.3 \\
\hline $\begin{array}{l}\text { Fucus spiralis } \\
\text { Ria de Vigo, N.W. Spain }\end{array}$ & Niel] (1977) & 2.0 \\
\hline $\begin{array}{l}\text { Himanthalia elongata } \\
\text { Ria de Vigo, N.W. Spain }\end{array}$ & Niell (1977) & 11.6 \\
\hline $\begin{array}{l}\text { Gracilaria tikvahiae } \\
\text { Mass outdoor cultures, Florida, } \\
\text { USA }\end{array}$ & $\begin{array}{l}\text { Lapointe and } \\
\text { Ryther (1979) }\end{array}$ & 13.0 \\
\hline $\begin{array}{l}\text { Saccorhiza polyschides } \\
\text { Associated with mussel raft } \\
\text { aquaculture in the Ria de Arosa, } \\
\text { N.W. Spain }\end{array}$ & This study & 10.2 \\
\hline
\end{tabular}


(1977) used measurements from well developed stands of the various intertidal species, and thus reflects maximum production rates; our measurements reflect average production rates based on random samples of mussel ropes. Even so, the production rate of $S$. polyschides is nearly that obtained with intensive outdoor mass cultures of the fast-growing red alga Gracilaria tikvahiae. These high rates of growth approach the upper limit of primary production (ca $15 \mathrm{~g} \mathrm{C} \mathrm{m}^{-2} \mathrm{~d}^{-1}$; Ryther, 1959) set by limitations of natural light to an aqueous, photosynthetic system.

Several features of the mussel-raft habitat support the extensive growth of Saccorhiza polyschides. First, the mussel ropes provide a three-dimensional surface for attachment of seaweeds that allows extremely high standing crops. For example, we found biomass levels of S. polyschides as high as $68 \mathrm{~kg} \mathrm{~m}^{-2}$ (wet wt.) during July at Station D on outside ropes where light is maximum. These biomass densities are greater than most published reports and are comparable to densities of $140 \mathrm{~kg} \mathrm{~m}^{-2}$ reported for the giant kelp Macrocystis in the Kerguelen Archipeligo of the Indian Ocean (Grua, 1964; Mann, 1972). Second, the relatively longer stipe length (decreased P:S) we observed for deeper growing $S$. polyschides in these dense stands may be a phytochrome response that allows deeper-growing plants to extend their blades upward toward the light, increasing light capture and growth. In a similar kelp, Nereocystis, stipe growth was suggested to be controlled by a phytochrome system; far-red irradiation promoted and near-red irradiation inhibited rapid stipe elongation (Duncan and Foreman, 1980). Other evidence suggests that phytochrome in terrestrial plants responds to changes in the ratio of quantum flux density at 660 and $730 \mathrm{~nm}(660: 730=\zeta)$ brought about by shading (Holmes and Smith, 1975; Holmes and Smith, 1977). Thus, under the dense Saccorhiza canopy, $\zeta$ may be appreciably decreased by absorption of red light by shallow-growing Saccorhiza plants and may induce rapid stipe growth of the deeper growing Saccorhiza Third, the continual $\mathrm{NH}_{4}{ }^{+}$regeneration by the mussels may stimulate the growth of $S$. polyschides. Several seaweeds preferentially and more efficiently utilize $\mathrm{NH}_{4}{ }^{+}$compared to $\mathrm{NO}_{3}{ }^{-}$(D'Elia and Deboer, 1978; Haines and Wheeler, 1978). These studies showed that kinetic patterns for uptake of $\mathrm{NO}_{3}$ and $\mathrm{NH}_{4}{ }^{+}$by seaweeds are quite different: $\mathrm{NO}_{3}{ }^{-}$ uptake follows saturable kinetics, whereas $\mathrm{NH}_{4}{ }^{+}$does not. The continual presence of $\mathrm{NH}_{4}{ }^{+}$may allow $S$. polyschides to increase its internal nitrogen reserves, which reduce effects of nitrogen limitation during high-light periods, and could lessen the importance of upwelled $\mathrm{NO}_{3}{ }^{-}$per se as a nitrogen source.

Even though the total area of mussel-rafts is relatively small, about $1 \%$ of the total surface areas of the
Ria de Arosa, seaweed production on the rafts contributes significantly to the primary production of the ria. If the average seaweed production at all 4 stations during the May-July period (4.8 $\mathrm{g} \mathrm{C} \mathrm{m}^{-2} \mathrm{~d}^{-1}$ ) is extrapolated to the total area of mussel rafts and compared with the total phytoplankton production in the ria during this period (assuming an average production rate of $0.6 \mathrm{~g} \mathrm{C} \mathrm{m}^{-2} \mathrm{~d}^{-1}$; Tenore and Gonzales, 1975), seaweed production associated with mussel-rafts account for ca $8 \%$ of the total phytoplankton production. However, if production of the extensive benthic littoral and sublittoral seaweed populations that occur in the ria were also considered, seaweeds would probably dominate primary production as they do in other north-temperate systems (Mann, 1972).

Acknowledgements. We wish to thank Mssr. Jim McClain and the many staff members of the Instituto Espanol de Oceanografia who participated in this research. Sr. D. Luis Losada Lago of Villagarcia, Spain, generously provided us with work space at his mussel-purification facility on Punta Preguntoiro. A very special thanks is due Dr Kenneth R. Tenore whose continual support and advice is credited with the completion of this manuscript. We also thank Dr. David W. Menzel and Dr. C. J. Dawes for their reviews of the manuscript. This research was conducted with funds from the Instituto Espanol de Oceanografia and Skidaway Institute of Oceanography under terms of the United States-Spanish Agreement for Friendship and Cooperation.

\section{LITERATURE CITED}

Ardre, F. (1957). Florule hivernale de la Ria de Vigo. Rev. Algol. 3(3): 135-196

Boudouresque, C. F., Lück, H. B. (1972). Recherches de bionomie structurale au niveau d'us peuplement benthic sciaphıle. J. exp. mar Biol. Ecol. 8: 133-144

Chapman, A. R. O. (1979). Biology of seaweeds, University Park Press, Baltimore

Connell, J. H., Slatyer, R. O. (1977). Mechanisms of succession in natural communities and their role in community stability and organization. Am. Nat. III: $1119-1144$

D'Elia, C, DeBoer, J. (1978). Nutritional studies of two red algae. II. Kinetics of ammonium and nitrate uptake. J. Phycol. 14: 266-272

Donze, M. (1968). The algal vegetation of the Ria de Arosa (N. W Spain). BIumea 16(1): 160-192

Druehl, L. D. (1967). Distribution of two species of Laminaria as related to some environmental tactors. J. Phycol. 3: 103-108

Duncan, M., Foreman, R. E. (1980). Phytachrome-mediated stipe elongation in the kelp Nereocystis (Phaeophyceae). J. Phycol. 16: 138-142

Fischer-Plette, A. (1963). La distribution des pruncipaux organisms nordiberiques en 1954-1955. AnnIs Inst. océanogr., Mónaco 40(3): 165-311

Foster, M. S. (1975). Algal succession in a Macrocystıs pyrifera Forest. Mar. Bıol. 32: 313-329

Fralick, R. A., Mathieson, A. C. (1975). Physiological Ecology of Four Polysiphonia species (Rhodophyta. Ceramiales) Mar Biol. 29: 29-36

Gallego, J. G. (1971). Estudio de las condiciones oceanograficas en la Ria de Arosa, en verano. Boln Inst. esp. Oceanogr $147 \cdot 1-39$ 
Gallego, J. E. (1975). Estudio de las condiciones oceanograficas en la Ria de Arosa en invierno. Boln Inst. esp. Oceanogr. 185: 1-53

Grua, P. (1964). Premieres donnees sur les biomasses de l'herbier a Macrocystis pyrifera de la baie du Morbihan (Archipel Kerguelen). Le Terra et la Vie, 2: 15-220

Gusst, G. G., Humm, H. J. (1976). Effects of sewage effluent on growth of Ulva lactuca. Fla Scient. 39: 267-271

Haines, K. C., Wheeler, P. A. (1978). Ammonid and nitrate uptake rates of the seaweeds Hypnea musciformis (Rhodophyta) and Macrocystis pyrifera (Phaeophyta). J. Phycol. 13 (Suppl.): 319-324

Holmes, M. G., Smith, H. (1975). The function of phytochrome in plants growing in the natural enviromment. Nature, Lond. 254: 512-514

Holmes, M. G., Smith, H. (1977). The function of phytochrome in the natural environment. IV Light quality and plant development. Photochem. Photobiol. 25: 551-558

Jerlov, N. G. (1968). Optical Oceanography, Elsevier, New York

John, D. M. (1971). The distribution and net productivity of sublittoral populations of attached macrophytic algae in an estuary on the Atlantic Coast of Spain. Mar Biol. 11: $90-97$

King, R. J., Schramm, W (1976). Photosynthetic rates of benthic marine algae in relation to light intensity and seasonal variations. Mar. Biol. 37: 215-222

Lapointe, B. E. (1981). The effects of light and nitrogen on growth rate, pigment content, and biochemical composition of Graciliaria foliifera v. angustissima (Rhodophyta, Gigartinales). J. Phycol., in press

Lapointe, B. E., Ryther, J. H. (1979). Some aspects of the growth and yield of Graciliaria tikvahiae in culture Aquaculture 15: 185-193

Lapointe, B. E., Tenore, K. R. (1981). Experimental outdoor studies with Ulva fasciata Delile I. Interaction of light and nitrogen on nutrient uptake, growth and biochemical composition. J. exp. mar. Biol. Ecol., in press

Lüning, K. Schmitz, K., Willenbrink, J. (1973). CO fixation and translocation in benthic marine algae. III. Rates and ecological significance of translocation in Laminaria hyperborea and L. saccharina. Mar. Biol. 23: 275-281

Mann, K. H. (1972). Macrophyte production and detritus food chains in coastal waters. Mem. Ist. ital. Idrobiol 29(Suppl.): 353-383

Margalef, R. (1963). Succession in marine populations. Adv. Front. Plant Sci. 2: 137-188

Margalef, R. (1969). Perspectives in ecological theory, The University of Chicago Press, Chicago

Newton, L. (1931). A handbook of British seaweeds, British Museum, London

Niell, F. X. (1974). Les applications de l'index de shannon a l'etude de la vegetation intertidale. Bull. Soc. Phycol. Fr. T. 19: $238-254$
Niell, F. X. (1977). Rocky intertidal benthic systems in temperate seas: A synthesis of their functional performances. Helgoländer wiss. Meeresunters. 30: 315-333

Niell, F. X. (1978). Catalogo floristico y fenologico de las algas superiores y cianoficeas bentonicas de las Rıas Bajas Gallegas. Inv. Pesqu. 42(2): 365-400

Niell, F. X. (1979). Structure and succession in rocky algal communities of a temperate intertidal system. J. exp. mar Biol. Ecol. 36: 185-200

Norton, T A. (1969). Growth form and environment in Saccorhiza polyschides. J. mar biol. Ass. U. K. 49: 1025-1045

Norton, T A., Burrows, E. M. (1969). Studies on marine algae of the British Isles. 7. Saccorhiza polyschides (Lightf) Batt. Br Phycol. J. 4(1): 19-53

Odum, E. P. (1969). The strategy of ecosystem development. Science, N. Y 164: 262-270

Otto, L. (1975). Oceanography of the Ria de Arosa. Meded. Verh. K. ned. met. Inst. 96: 210 pp.

Phillips, R. W. (1896). Note on Saccorhiza bulbosa. J. G. Ag. and Alaria esculenta Grev. Ann. Bot. 19: 96-97

Pielou, E. C. (1966). The measurement of diversity in different types of biological collections. J. theor Biol. 13: 131-144

Prentice, S. A., Kain, J. M. (1976). Numerical analysis of subtidal communities on rocky shores. Estuar. coast. mar sci. $4: 65-70$

Prescott, G. W. (1968). The algae: a review, Houghton Mifflin Co., Boston

Ramus, J. (1978). Seaweed anatomy and photosynthetic performance: the ecological significance of light guides, heterogeneous adsorption and multiple scatter. J. Phycol. 14: $352-362$

Roman, G., Perez, A. (1979). V Estudio del mejillon y de su epifauna en los cultivos flotantes de la Ria de Arosa. II. Crecimiento, mortalidad y produccion del mejillon. Boln Inst. esp. Oceanogr. 1: 266

Ryther, J. H. (1959). Potential productivity of the sea. Science, N. Y 130: $602-608$

Sanders, H. T. (1960). Benthic studies in Buzzards Bay. II. The structure of the soft-bottom community. Limnol. Oceanogr. 5(2): 138-153

Seoane, J. (1957). Algas superiores de las Rias Bajas Gallegas. Inv. Pesqu. 8: 15-28

Sousa, W. P. (1979). Experimental investigations of disturbance and ecological succession in a rocky intertidal algal community. Ecol. Monogr. 49(3): 227-254

Tenore, K. R., Gonzalez, N. (1975). Food chain patterns in the Ria de Arosa. Spain: An area of intense mussel aquaculture. 10th European Symposium on Marine Biology, Ostend, Belgium, Vol. 2. Universa Press, Wetteren, pp. 601-619

Wilhm, J. L. (1968). Use of biomass units in Shannon's formula. Ecology 49: 153-156 